\title{
Kesesuaian Fatwa DSN MUI No. 4 Tahun 2000 Pada Pembiayaan Murabahah di Bank Syariah Mandiri KCP Padang Panjang
}

\section{Rahmat Firdaus}

Fakultas Ekonomi dan Bisnis Islam, Institut Agama Islam Negeri Batusangkar, firdausrabmat157@gmail.com

\section{Melisantri Okvita}

Fakultas Ekonomi dan Bisnis Islam, Institut Agama Islam Negeri Batusangkar, melisantriokvita97@gmail.com

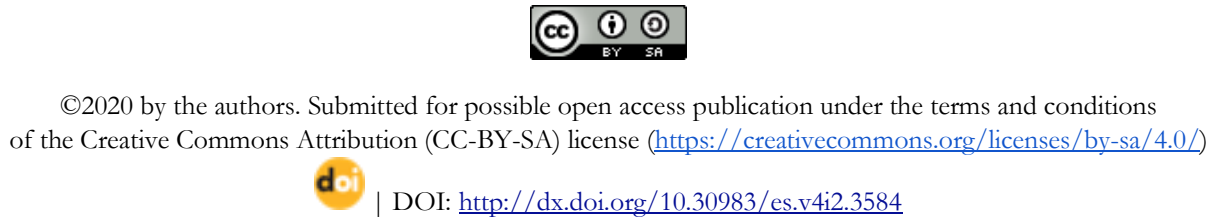

Abstract

The purpose of this study was to determine and analyze the implementation of murabahah financing at Bank Syariah Mandiri KCP Padang Panjang its conformity with MUI DSN Fatwa No. 4 of 2000. This research is field research with a qualitative research methods. Data collection techniques are observation, interview and documentation. The results showed that in the general provisions of the murabahah fatwa in Islamic banks, namely banks buy goods needed by customers on behalf of the bank itself and the purchases must be valid and free of usury. However, in practice in the field, the bank gives money to customers to buy one of the items needed on behalf of the bank with an installment system based on the amount and time set by the bank. This is allowed by the scholars on the condition that the bank authorizes the customer to buy goods with the murabahah bil wakalah contract.

Key words: Fatwa, DSN MUI, Murabahah

\begin{abstract}
Abstrak
Tujuan dalam penelitian ini adalah untuk mengetahui dan menganalisis pelaksanaan pembiayaan murabahah pada Bank Syariah Mandiri KCP Padang Panjang kesesuaiannya dengan Fatwa DSN MUI No. 4 Tahun 2000. Jenis penelitian adalah penelitian lapangan field research. Metode penelitian yang digunakan adalah metode penelitian kualitatif. Teknik pengumpulan data adalah observasi, wawancara dan dokumentasi. Hasil penelitian menunjukkan bahwasannya dalam ketentuan umum fatwa murabahah di bank syariah yaitu bank membeli barang yang dibutuhkan nasabah atas nama bank sendiri dan pembelian harus sah dan bebas riba. Akan tetapi pada prakteknya dilapangan adalah bank memberikan uang kepada nasabah untuk membeli salah satu barang yang dibutuhkan atas nama bank dengan sistem angsuran berdasarkan jumlah dan waktu yang telah ditetapkan oleh bank. Hal ini dibolehkan oleh ulama dengan ketentuan pihak bank menguasakan kepada nasabah untuk membeli barang dengan akad murabahah bil wakalah.
\end{abstract}

Kata kunci: Fatwa, DSN MUI, Murabahah 


\section{Latar Belakang}

Negara berpenduduk Muslim terbesar di dunia adalah Indonesia sehingga pada abad XX ini telah banyak lembaga keuangan bank ataupun non banak yang menerapkan prinsip Syariah. Pada awal-awal berdirinya negara Indonesia, perbankan masih berpegang pada sistem konvensional atau sistem bunga bank (interest system). Lahirnya bank syariah di Indonesia sejak tahun 1992. Bank syariah pertama di Indonesia adalah Bank Muamalat Indonesia. Pada tahun 1992 hingga 1999 perkembangan Bank Muamalat Indonesia, masih tergolong stagnant. Namun sejak adanya krisis moneter yang melanda Indonesia pada tahun 1997 dan 1998, maka para bankir melihat bahwa Bank Muamalat Indonesia (BMI) tidak terlalu terkena dampak krisis moneter. Dan pada tahun 1999, berdirilah Bank Syariah Mandiri yang merupakan konversi dari Bank Susila Bakti. Bank Susila Bakti merupakan bank konvensional yang dibeli oleh bank dagang negara, kemudian dikonversi menjadi Bank Syariah Mandiri, bank syariah kedua di Indonesia. ${ }^{1}$

Munculnya bank berawal dari berkembangnya model penyimpanan harta benda. Pada masa itu manusia takut dan cemas jika membawa uang dan perhiasan mereka dalam jumlah banyak karena mereka berpindah-pindah tempat, sedangkan orangorang jahat terus membayang-bayangi. Bank adalah suatu lembaga keuangan yang dipercaya oleh masyarakat tempat yang aman dalam menyimpan harta benda dengan

${ }^{1}$ Abdul Latif, 'Implementasi Fatwa DSN-MUI

Terhadap Praktik Pembiayaan Murabahah Bank Syariah Mandiri Dan Bank Muamalat KCP Ponorogo', Muslim Heritage, 2016

<https://doi.org/10.21154/muslimheritage.v1i1.379>. Rahmat Firdaus \& Melisantri Okvita penjagaan yang ketat oleh manusia dan teknologi yang canggih seperti CCTV sehingga sulit bagi para pencuri untuk membobol bank. Pada masa Rasulullah dan para sahabat telah ada praktek perbankan, walaupun belum di aplikasikan seluruhnya. Akan tetapi telah ada sahabat yang mempraktekkan peran bank seperti, menerima titipan harta, memberi pinjaman, pengiriman uang, ada juga yang memberikan modal usaha untuk berdagang. Oleh karena itu, praktikpraktik perbankan telah biasa dilakukan di masa Rasulullah. ${ }^{2}$

Kemajuan suatu Negara sangat ditentukan dengan adanya bank "urusan pembayaran, perdagangan dan pembengunan ekonomi" karena bank berfungsi sebagai pengumpul uang dan menyalurkannya kembali kepada perusahaan-perusahaan yang membutuhkan tambahan modal. Kemajuan suatu perusahaan juga tergantung adanya bank sebagai fasilitator modal dengan begitu suatu perusahaan dapat bergerak lebih luas dalam usaha bisnisnya jika suntikan modal ada dari bank. ${ }^{3}$ Adanya bank sangat membantu perekonomian Negara apalagi di masa pandemi covid-19 saat ini instrument bank sangat dibutuhkan dalam mengatur stabilitas ekonomi dan peredaran uang di tengah-tengah masyarakat.

Ada bank yang menjalankan bisnisnya dengan sistem bunga dan ada juga bank yang menjalankan bisninya dengan sistem bagi hasil. Bank yang menjalankan bisnis usahanya dengan sistem bagi hasil yang disebut dengan

2 Rachmadi Usman, Aspek Hukum Perbankan Syariah Di Indonesia (: Sinar Grafika, 2014). h.1

3 Syukri Iska, Sistem Perbankan Syariah Di Indonesia (: Fajar Media Press, 2016). h. 16

Kesesuaian Fatwa DSN.... 
menerima laporan dari DPS. DSN dapat

sistem bagi hasil yang disebut dengan bank syariah. Salah satu skim yang paling banyak yang dipraktekkan oleh perbankan syariah adalah jual beli murabahah. Pada dasarnya murabahah adalah suatu akad penjualan barang tertentu seharga barang tersebut ditambah margin yang disetujui. Begitu juga pada Bank Syariah Mandiri KCP Padang Panjang, pembiayaan murabahah hadir untuk mewujudkan impian masyarakat dalam perekonomian yang lemah dari segi modal usaha.

Pembiayaan murabahah merupakan produk yang berdasarkan jual beli secara angsuran dengan mendapatkan margin keuntungan. Walaupun murabahah merupakan akad yang popular bukan berarti prakteknya di lapangan telah sesuai pada ketentuan dan prinsip syariah. Implementasi operasional tersebut harus dipastikan berjalan sesuai dengan prinsip dan ketentuan syariah sebagaimana yang tertuang dalam Fatwa Dewan Syariah Nasional Majelis Ulama Indonesia (DSN MUI), landasan hokum positif Indonesia serta ketentuan Standar Syariah Internasional.

Ketentuan tentang murabahah banyak termuat dalam fatwa DSN MUI. Dewan syariah Nasional merupakan lemabaga yang dibentuk dalam rangka merealisasikan keinginan umat Islam dalam hal perekonomian serta mendorong penerapan syariah Islam pada bidang perekonomian dan keuangan. Dewan syariah nasional memiliki fungsi sebagai peneliti dan pemberi fatwa bagi produk yang dikembangkan oleh lembaga keuangan syariah dan juga dapat memberikan teguran jika terdapat lembaga keaungan syariah mengeluarkan produk tidak sesuai fatwa. Hal ini dilakukan setelah DSN mengusulkan pada otoritas yang berwenang seperti Bank Indonesia agar memberikan sanksi pada lembaga keuangan syariah yang tidak sesuai fatwa DSN MUI. ${ }^{4}$ Pada awal perkembangannya perbankan syariah menawarkan beragam produk perbankan yang bebas bunga berupa pembiayaan bagi hasil atau yang popular dikenal sebagai Profit and Loss Sharing (PLS) dan pembiayaan murabahah. Seiring berjalannya waktu, pembiayaan bagi hasil ternyata sulit untuk diterapkan karena pada produk-produk berbasis PLS bank disamping berbagi keuntungan dengan nasabah juga harus berbagi kerugian. ${ }^{5}$ Secara umum tugas bank syariah sebagai berikut:

1. Mengumpulkan dana dalam bentuk simpanan seperti akada wadiah. Selain dalam bentuk simpanan ada juga dalam bentuk investasi seperti akad mudharabah.

2. Menyalurkan pembiayaan bagi hasil penyewaan barang bergerak atau tidak bergerak kepada nasabah berdasarkan akad ijarah.

3. Pelaksana kegiatan social. Hal ini seorang manajer investasi mengambil kedudukan menyarankan tempat penyaluran dana.

4. Penyedia jasa keuangan. Bank syariah bertugas menyediakan jasa keuangan. Hal ini tentu berbeda dengan bank konvensional yang menggunakan prinsip bunga dalam

${ }^{4}$ Fauziyah, 'Penerapan Akad Murabahah Sesuai Fatwa DSN-MUI Studi Kasus Pada BRI Syariah KCP Lubuk Pakam' (UIN Sumatera Utara, 2019) $<$ http://repository.uinsu.ac.id/id/eprint/7145>.

5 Novi Fadhila, Analisis Pembiayaan Mudharabah Dan Murabahah Terhadap Laba Bank Syariah Mandiri, Riset Akuntansi Dan Bisnis, 2015, h. 65

Kesesuaian Fatwa DSN.... 
praktiknya sehingga memberatkan masyarakat dalam pengembalian hutang. Sementara dalam bank syariah tidak dikenal istilah bunga atau riba karena bertentangan dengan syariah Islam.

5. Mewujudkan kesejahteraan dan keadilan ekonomi. Tidak ada potongan uang jika masyarakat menabung di bank syariah. Kesemuanya itu bertujuan agar terciptanya kesejahteraan dan keadilan ekonomi serta dapat mengurangi tingkat inflasi setiap tahun.

6. Promosi halal. Adanya bank syariah dapat mendorong berkembangnya pengusaha syariah baik dari tingkat makro dan mikro. Sekain mempromosikan benefi-benefit yang fair di bank syariah. Promosi halal tentunya dapat meningkatkan promosi halal tentunya dapat meningkatkan investasi dengan keuntungan yang didapat lebih transparan dan merata. Seperti bank mandiri syariah yang merupakan BUMN akan menjadi contoh di dalam ekonomi Indonesia. Apabila dalam prakteknya gagal tentu pada akhirnya gulung tikar, maka kelangsungan promosi halal dan pertumbuhan ekonomi syariah dapat terhambat.

7. Mendorong tumbuhnya ekonomi. Semua kemudahan yang disediakan oleh perbankan syari'ah menjadi pendorong bagi masyarakat yang ingin memiliki niatan berusaha. Usaha disini diartikan mendirikan suatu badan usaha atau unit usaha ekonomi yang dapat menghasilkan peluang kerja dan pendapatan. Dengan begitu kesejahteraan rakyat akan meningkat. Proses yang mudah di bank syariah tentunya dapat menarik kaum emiten kecil agar lekas memulai usaha. ${ }^{6}$

Berdasarkan wawancara penulis dengan bapak Iswandi sebagai BM (Branch Manager) dan Ibu Fauziah sebagai JCBRM (Junior Customer Banking Relation Manager), di Bank Syariah Mandiri KCP Padang Panjang. Penulis mewawancarai terkait pelaksanaan akad pembiayaan murabahah. Narasumber mengatakan bahwa pembiayaan murabahah merupakan akad pembiayaan yang diberikan kepada nasabah untuk keperluan seperti untuk membeli kendaraan baik itu mobil atau motor, pembelian rumah dan kebutuhan lainnya. ${ }^{7}$

\section{Metodologi Penelitian}

Penulis menggunakan metode gabungan antara penelitian lapangan dan penelitian pustaka dengan metode kualitatif secara deskriptif analisis. Lokasi penelitian di Bank Syariah Mandiri KCP Padang Panjang. Penulis menggunakan data primer yang bersumber dari studi lapangan berupa informasi yang berasal dari para praktisi pada pada Bank Syariah Mandiri KCP Padang Panjang. BM (Branch Manager) JCBRM (Junior Cunsumer Banking Relation Manager), dilakukan dengan cara wawancara terarah (guided interview) individual dan diskusi. Penelitian lapangan (field research) penulis mengamati langsung setiap peristiwa atau kejadian yang ada di lapangan atau fenomena yang ada ditempat

6 https://panduanbank.com/bank-syariah diakses tanggal 19 September 2020

${ }^{7}$ Iswandi dan Fauziah, Wawancara, 1 juni 2020 Kesesuaian Fatwa DSN.... 
penelitian. Metode ini digunakan untuk meneliti pada kondisi objek alamiah, dimana peneliti merupakan instrument kunci. ${ }^{8}$ Peneliti mengambil jenis penelitian ini karena melakukan pengamatan terhadap pelaksanaan akad pembiayaan murabahah yang ada di Bank Syariah Padang Panjang kesesuaiannya dengan fatwa DSN MUI No. 4 Tahun 2000.

Penulis juga menggunakan kajian kepustakaan (library research). Suatu jenis penelitian yang membatasi kegiatan pada bahan-bahan koleksi perpustakaan dan studi dokumen. ${ }^{9}$ Sumber data yang menjadi bahan kajian pada penelitian ini adalah data sekunder. Seperti buku, jurnal, artikel hasil penelitian yang terkait tentang pelaksanaan pembiayaan murabahah di lembaga keuangan syariah.

\section{Hasil dan Pembahasan}

\section{Pelaksanaan Pembiayaan Murabahah di Bank Syariah Mandiri KCP Padang Panjang}

Saat sekarang ini lembaga keuangan syariah telah dikenal secara luas di Indonesia. Salah satu lembaga keuangan syariah adalah bank syariah. Lembaga keuangan ini pada prakteknya telah menggunakan akad - akad seperti murabahah, mudharabah, dan musyarakah. Murabahah adalah akad jual beli antara dua pihak yang berakad, yang mana pembeli dan penjual bersepakat tntang harga jual suatu barang tertentu yaitu harga beli ditambah kentungan bagi penjual. Pelaksanaan pembiayaan murabahah di bank syariah KCP

\footnotetext{
8 Sugiyono, Metode Peneiltian Kuantitatif, Kualitatif Dan R\&D, Alfabeta Bandung, 2018. h. 9

${ }^{9}$ IAIN Imam Bonjol Padang, Pedoman Penulisan Karya Ilmiah (Tugas Akhir, Skripsi, Tesis, Dan Disertasi (Indonesia, 2014). h. 48
}

Rahmat Firdaus \& Melisantri Okvita
Padang Panjang merupakan suatu bentuk pembiayaan yang diberikan oleh pihak bank kepada nasabah untuk pembelian suatu produk tertentu. Di bawah ini terdapat produk-produk pembiayaan murabahah di bank syariah mandiri KCP Padang Panjang yaitu:

1. Pembiayaan konsumtif gunanya untuk pembiayaan pembelian rumah

2. Pembiayaan multiguna untuk pembiayaan mitraguna

3. Pembiayaan pra pensiun yaitu pembiayaan khusus bagi nasabah yang akan pensiun

4. Pembiayaan pensiun yaitu pembiayaan mitra guna khusus bagi nasabah pensiun

5. Pembiayaan kendaraan baik kendaraan baru maupun kendaraan bekas

6. Pembiayaan mikro adalah pembiayaan untuk modal kerja

Produk pembiayaan yang paling banyak diminati nasabah pada bank syariah mandiri KCP Padang Panjang adalah pembiayaan konsumtif seperti: renovasi rumah, pembeliah rumah, pembelian kendaraan dan lain-lain. Pelaksanaan pembiayaan murabahah pada bank syariah mandiri KCP padang panjang diawali dengan nasabah pergi ke bank syariah mandiri kcp padang panjang untuk mengajukan pembiayaan. Nasabah harus melengkapi syarat-syarat yang sudah ditentukan oleh bank yaitu dokumen-dokumen seperti KTP suami istri bagi yang sudah menikah, KK, NPWP, surat nikah, SK bagi PNS, keterangan gaji dan laporan keuangan usaha dan juga nasabah harus menyediakan jaminan atau agunan Kesesuaian Fatwa DSN.... 
seperti sertifikat tanah,rumah, BPKB mobil, dan hal-hal yang mungkin bisa dijadikan jaminan yang bisa diuangkan, nilai jaminan harus lebih dari nilai pembiayaan. Kemudian pihak bank melakukan verifikasi data dengan melakukan BI Checking untuk melihat apakah nasabah yang akan melakukan pembiayaan ada masalah dengan bank lain atau atau pernah macet dalam melakukan pembayaran di bank sebelumnya. Jika nasabah memiliki masalah tersebut berarti nasabah memiliki kriteria etika yang tidak baik maka bank akan menolak untuk diberikan pembiayaan, akan tetapi jika nasabah tidak memiliki masalah dan tidak pernah macet dalam melakukan pembayaran maka bank akan menerima dan dilanjutkan ke proses selanjutnya. Setelah itu bank menverivikasi Kartu Tanda Penduduk nasabah untuk melihat domisili nasabah karena di Bank Syariah Mandiri KCP Padang Panjang berlaku wilayah teritorial yaitu PABASKO (Padang Panjang, Batipuh, dan Sepuluh koto, ) jadi nasabah diluar daerah tersebut tidak bisa mengajukan pembiayaan ke Bank Syariah Mandiri KCP Padang Panjang, hal ini untuk memudahkan bank jika terjadi kemacetan dalam angsuran pembayaran nasabah. Setelah verifikasi KTP selanjutnya verifikasi surat nikah, bagi suami istri harus ada surat nikah dan harus saling mengetahui bahwa akan melakukan pembiayaan, tidak boleh hanya salah satu pihaksaja yang mengajukan pembiayaan, ini dilakukan agar jika terjadi permasalahan bank akan menghubungi kedua pihak tersebut. Kemudian setelah itu pihak bank menverifikasi Nomor Pokok Wajib Pajak (NPWP ) kemudian verifikasi usaha nasabah, berapa pendapatannya, ini dilakukan untuk melihat kesanggupan nasabah dalam membayar angsurannya. Setelah itu bank akan verivikasi agunan, misalnya nasabah mengajukan pinjaman 200 juta akan tetapi nilai agunannya 100 juta maka bank tidak bisa menerima pinjaman nasabah tersebut, akan tetapi jika nilai agunan lebih dari nilai pinjaman maka bank akan memproses pinjaman nasabah tersebut. Setelah semua data dan jaminana terverifikasi selanjutnya dibuatkan dokumen akan pembiayaan murabahah lalu ditandatangani dan disetujui oleh pihak yang bersangkutan. Selanjutnya baru dilakukan pencairan dana, baru nasabah melakukan kewajibannya untu membayar angsuran sesuai jumlah dan waktu yang telah ditetapkan di akad. Jika nasabah mengajukan pembiayaan pembelian kendaraan maka bank akan memberikan uang sejumlah permintaan nasabah dan nasabah sendiri yang membeli kedaraan tersebut ke pihak pemasok atas nama nasabah sendiri dan nasabah akan mengangsur sesuai kesepatan di dalam akad. Bagi nasabah yang mengalami kemacetan dalam pembayaran angsurannya maka bank akan memprosesnya dengan melihat kendala yang dialami nasabah, jika nasabah mengalami musibah seperti kebakaran, meninggal, usaha menurun maka bank akan memberikan kelonggaran bagi nasabah yaitu dengan cara merestrukrur angsuran nasabah, misalnya semula angsuran nasabah tersebut sebesar Rp. 2000.000,- kemudian karena ada masalah nasabah hanya mampu membayar sebesar Rp. 500.000,- maka bank akan menerima kesanggupan nasabah tersebut agar bisa melunasi hutang-hutangnya.

Akan tetapi jika nasabah sengaja lalai dan tidak membayar angsuran maka bank akan memperingati nasabah untuk membayar angsurannya, jika nasabah tidak juga membayar kewajibannya maka bank akan 
melelang jaminan yang diberikan nasabah tersebut, itulah sebabnya nilai agunan nasabah harus melebihi nilai pinjamannya karena jika nasabah tidak sanggup membayar dan lari dari tanggung jawabnya maka bank akan melelang jaminanan dengan harga pasar, jika sudah terjual jaminannya uang tersebut akan digunakan untuk melun asi sisa hutang nasabah. Jika masih ada sisa dari uang pelelangan jaminan tersebut maka akan diserahkan kembali ke nasabah. Jika kurang maka bank akan meminta kembali ke nasabah untuk membayar sisa hutangnya, akan tetapi hal ini jarang terjadi karena nilai jaminan yang ditetapkan bank lebih besar dari nilai jaminan yang diberikan oleh nasabah.

Analisis kesesuaian Fatwa DSN MUI No. 4 Tahun 2000 Pada Pembiayaan Murabahah di Bank Syariah Mandiri KCP Padang Panjang

Pembiayaan murabahah di Bank Syariah Mandiri KCP Padang Panjang merupakan salah satu bentuk talangan pembiayaan yang dibutuhkan oleh masyarakat guna membeli suatu produk atau barang tertentu dengan ketentuan, nasabah mengembalikan pembiayaan tersebut pada waktu jatuh tempo dan ditambah dengan margin yang disepakati dengan pihak bank. Adapun ketentuan fatwa murabahah antara pihak bank syariah dengan nasabah sebagai berikut:

Pertama, ketentuan umum murabahah dalam bank syariah:

a. Bank dan nasabah harus melakukan akad murabahah yang bebas riba. ${ }^{10}$

${ }^{10}$ Fatwa DSN MUI No. 4 Tahun 2000

tentang Murabahah

Rahmat Firdaus E Melisantri Okvita
Sudah sesuai karena Pelaksanaannya di BSM adalah bank menjelaskan kepada nasabah setiap biayabiaya yang dikeluarkan oleh bank dijelaskan secara rinci kepada nasabah begitu juga jumlah bagi hasil yang diperoleh bank atas pinjaman yang diberikan kepada nasabah.

b. Barang yang diperjualbelikan tidak diharamkan oleh syariah Islam.

Sudah sesuai dengan yang dilaksanakan oleh bank syariah mandiri KCP Padang Panjang yaitu barang yang diperjualbelikan atau yang dibiayai oleh bank tidak ada yang diharamkan oleh bank cntohnya bank membiayai pembelian atau renovasi rumah, pembelian kendaraan baik itu mobil atau motor, dan pembiayaan untuk usaha yang halal.

c. Bank membiayai sebagian atau seluruh harga pembelian barang yang telah disepakati kualifikasinya.

Sudah sesuai dengan pelaksanaannya di BSM karena bank membiayai sebagian atau seluruh pengajuan yang diajukan oleh nasabah karena kadang nasabah sudah mempunyai sedikit dana jadi hanya untuk menambah kekurangan dari dana nasabah.

d. Bank membeli barang yang diperlukan nasabah atas nama bank sendiri, dan pembelian ini harus sah dan bebas riba.

$$
\text { Belum sesuai dengan }
$$
pelaksaannya di Bank Syariah Mandiri KCP Padang Panjang karena untuk pembelian barang bank menyerahkan uang kepada nasabah dan nasabah sendiri

Kesesuaian Fatwa DSN.... 
yang membeli ke pihak ketiga atas nama nasabah bukan atas nama bank.

e. Bank harus menyampaikan semua hal yang berkaitan dengan pembelian, misalnya jika pembelian dilakukan secara utang.

Belum sesuai karena pada pelaksaannya bank tidak membelikan barang yang diinginkan nasabah, bank hanya memberikan uang berdasarkan permintaan nasabah yang disepati dan jika ada kekurangan dana atas pembelian tersebut nasabahlah yang membayarnya.

f. Bank kemudian menjual barang tersebut kepada nasabah (pemesan) dengan harga jual senilai harga beli plus keuntungannya. Dalam kaitan ini dengan bank harus memberitahu secara jujur harga pokok barang kepada nasabah berikut biaya yag diperlukan.

Belum sesuai karena bukan bank yang membeli barang yang diinginkan nasabah jadi bank hanya bertindak sebagi pemberi dana bukan penjual. Yang dijelskan dalam akad ini oleh pihak bank adalah keuntungan atau bagi hasil yang didapatkan oleh bank atas pembiayaan yang diberikan kepada nasabah.

g. Nasabah membayar harga barang yang telah disepakati tersebut pada jangka waktu tertentu yang telah disepakati.

Sudah sesuai dengan pelaksanaannya di BSM karena setelah terjadinya pencairan dana maka setelah itu nasabah wajib membayar angsuran berdasarkan jumlah dan waktu yang telah disepakati.

h. Untuk mencegah terjadinya penyalahgunaan atau kerusakan akad tersebut, pihak bank dapat mengadakan perjanjian khusus dengan nasabah.
Sudah sesuai pelaksanaannya di Bank Syariah Mandiri KCP Padang Panjang karena setiap pembiayaan yang diajukan nasabah akan dibuatkan kontrak perjanjian agar nasabah serius dalam melakukan pembiayaan dan tidak lari dari tanggungjawab, dan tidak terjadi kerugian antara kedua belah pihak.

i. Jika bank hendak mewakilkan kepada nasabah untuk membeli barang dari pihak ketiga, akad jual beli murabahah harus dilakukan setelah barang secara prinsip menjadi milik bank.

Belum sesuai dengan pelaksanaannya di Bank Syariah Mandiri KCP Padang Panjang karena jika bank ingin mewakilkan pembeliannya kepada nasabah seharusnya barang tersebut secara prinsip sudah milik bank. Akan tetapi di Bank Syariah Mandiri KCP Padang Panjang bank tidak membelikan barang ersebut kepada pihak ketiga akan tetapi bank hanya memberikan uang kepada nasabah dan nasabah sendiri yang membeli barang tersebut atas nama bank sendiri.

Kedua, Ketentuan murabahah kepada nasabah

a. Nasabah mengajukan permohonan dan janji pembelian suatu barang atau aset kepada bank.

Sudah sesuai pelaksanaannya di Bank Syariah Mandiri KCP Padang Panjang karena untuk melakukan pembiayaan nasabah datang ke bank untuk mengajukan pembiayaannya beserta persyaratan yang telah ditentukan oleh bank.

b. Jika bank menerima permohonan tersebut, ia harus membeli terlebih 
dahulu aset yang dipesannya secara sah dengan pedagang.

Belum sesuai pelaksanaannya di Bank Syariah Mandiri KCP Padang Panjang karena setelah permohonan nasabah disetujui oleh bank, bank memberikan uang sesuai yang telah disepakati kepada nasabah dan nasabah sendiri yang membeli barang tersebut kepada pihak ketiga atas nama nasabah sendiri.

c. Bank kemudian menawarkan aset tersebut kepada nasabah dan nasabah harus menerima (membeli) nya sesuai dengan janji yang telah disepakatinya, karena secara hukum janji tersebut mengikat; kemudian kedua belah pihak harus membuat kontrak jual beli.

Belum sesuai pelaksanannya di Bank Syariah Mandiri KCP Padang Panjang karena bank tidak membelikan barang yang diinginkan oleh nasabah, nasabah sendiri yang membeli barang tersebut kepada pihak ketiga atas nama bank sendiri dan ditempat yang diinginkan oleh nasabah.

d. Dalam jual beli ini bank dibolehkan meminta nasabah untuk membayar uang muka saat menandatangani kesepakatan awal pemesanan.

Sudah sesuai pelaksanannya di BSM boleh meminta uang muka kepada nasabah jika nasabah sudah memiliki dana dan bank akan membiayai kekurangan dana yang dibutuhkan nasabah.

e. Jika nasabah kemudian menolak membeli barang tersebut, biaya riil bank harus dibayar dari uang muka tersebut.

f. Jika nilai uang muka barang kurang dari kerugian yang harus ditanggung oleh bank, bank dapat meminta kembali sisa kerugiannya kepada nasabah.

g. Jika uang muka memakai kontrak 'urbun sebagai alternatif dari uang muka, maka:

1) Jika nasabah memutuskaan untuk membeli barang tersebut, ia tinggal membayar sisa harga.

2) Jika nasabah batal membeli, uang muka menjadi milik bank maksimal sebesar kerugian yang ditanggung oleh bank akibat pembatalan tersebut dan jika uang muka tidak mencukupi, nasabah wajib melunasi kekurangannya.

Poin e sampai g belum sesuai pelaksanaannya dengan yang dilakukan oleh Bank Syariah Mandiri KCP Padang Panjang karena barang yang diinginkan nasabah bukan bank yang membelikannya kepada pihak ketiga akan tetapi nasabah sendiri yang membelinya atas nama nasabah kemudian mengenai uang muka jika diberikan oleh nasabah uang muka tersebut digunakan untuk mengurangi jumlah hutang nasabah.

Ketiga, jaminan dalam murabahah:

a. Jaminan dalam murabahah dibolehkan, agar nasabah serius dengan pesanannya.

Pelaksanaannya di Bank Syariah Mandiri KCP Padang Panjang nasabah harus memberikan jaminan atas pembiayaan yang diajukannya Kesesuaian Fatwa DSN.... 
karena untuk menghindari hal-hal yang tidak diinginkan dikemudian hari. Dan jaminan yang diberikan haru melebihi jumlah pinjamannya.

b. Bank dapat meminta nasabah untuk menyediakan jaminan yang dapat dipegang.

Sudah sesuai Pelaksanaannya di Bank Syariah Mandiri KCP Padang Panjang karena nasabah boleh memberikan jaminan seperti BPKB mobil sertifikat tanah dan lain-lainnya yang dapat diuangkan yang dapat dipegang dan melebihi nilainya dari jumlah pembiayaan yang diberikan oleh bank.

Keempat, utang dalam murabahah:

a. Secara prinsip penyelesaian utang nasabah dalam transaksi murabahah tidak ada kaitannya dengan transaksi lain yang dilakukan nasabah dengan pihak ketiga atas barang tersebut. Jika nasabah menjual kembali barang tersebut denga keuntungan atau kerugian, dia tetap berkewajiban untuk menyelesaikan utangnya kepada bank.

Sudah sesuai pelaksanaannya dengan yang dilakukan oleh Bank Syariah Mandiri KCP Padang Panjang karena jika barang yang dibiayai oleh bank pembeliannya jika dijual sebelum akad berakhir maka tidak mempengaruhi akad antara nasabah dengan bank, nasabah tetap memiliki kewajiban untuk membayar hutangnya sesuai jumlah dan waktu yag telah ditetapkan.

b. Jika nasabah menjual barang tersebut sebelum masa angsuran berakhir, dia tidak wajib segera melunasi seluruh angsurannya.

Sudah sesuai karena Pada pelaksanaannya jika barang yang dibeli nasabah dijual sebelum masa pembiayaan berakhir nasabah tidak wajib mebayar lunas angsurannya karena pebayaran angsuran sesuai dengan waktu dan umlah yang ditentukan sampai akhir, kecuali jika nasabah ingin melunasi hutangnya atas kemauannya sendiri.

c. Jika penjualan barang tersebut menyebabkan kerugian, nasabah tetap harus menyelesaikan utangnya sesuai kerugian awal. Ia tidak boleh memperlambat pembayaran angsuran atau meminta kerugian itu diperhitungkan.

Begitu juga jika terjadi kerugian atas penjualan barang tersebut misalnya penjualan barang tersebut dengan harga yang murah maka nasabah tetap membayar angsurannya sesuai dengan kesepakatan di awal, kerugiannya tidak mempengaruhi akad.

Kelima, penundaan pembayaran dalam murabahah:

a. Nasabah memiliki kemampuan tidak dibenarkan menunda penyelesaian utangnya.

Sudah sesuai karena di Bank Syariah Mandiri KCP Padang Panjang bagi nasabah yang memilki kemampuan untuk membayar dan sengaja tidak membayar kewajibannya maka akan diberi peringatan untuk membayar angsurannya tepat waktu. 
b. Jika nasabah menunda-nunda pembayaran dengan sengaja, atau jika salah satu pihak tidak menunaikan kewajibannya, maka penyelesaikannya dilakukan melalui Badan Arbitrasi Syariah.

Sudah sesuai karena bagi nasabah yang sengaja melalaikan bahkan tidak membayar angsurannya tanpa ada alasan yang jelas dan sudah diperingatkan tetapi tidak diindahkan maka akan diselesaikan dengan badan arbitrasi syariah. Jika tidak ada tanggapan dan kesadaran dari pihak nasabah maka akan dilakukan penyitaan jaminan.

Keenam, bangkrut dalam murabahah:

Jika nasabah telah dinyatakan pailit dan gagal menyelesaikan utangnya, bank harus menunda sampai ia jadi sanggup kembali, atau berdasarkan kesepakatan.

Berbeda dengan nasabah yang sengaja menunda pembayarannya, bagi nasabah yang menunda pembayarannya dikarenakan karena hal-hal yang tidak direncanakan seperti terjadinya bencana alam seperti banjir, gempa dan lain-lain , kematian, dan bangkrut, maka bank memberikan kelonggaran sampai nasabah sanggup kembali untuk membayar angsurannya atau dilakukan restrukrur untuk agar nasabah bisa membayar angsuran berdasarkan kesanggupannya.

Analisis Peran Dewan Pengawas Syariah Terhadap Kepatuhan Lembaga Keuangan Syariah di Indonesia

Bank syariah harus menjalankan fungsinya dengan baik sesuai dengan ketentuan perbankan yang berlaku dan juga sesuai pula dengan prinsip syariah. Untuk menjamin terlaksananya prinsip syariah, dalam aktifitas perbankan syariah terdapat salah satu pihak terafiliasi yaitu Dewan Pengawas Syariah (DPS) yang memberikan jasanya kepada bank syariah. Dewan inilah sebagai pihak yang bertanggungjawab atas informasi tentang kepatuhan pengelola bank akan prinsip syariah.

Dewan Pengawas Syariah (DPS) adalah dewan yang melakukan pengawasan terhadap prinsip syariah dalam kegiatan usaha bank syariah yang dalam menjalakan fungsinya bertindak secara independen. DPS terdiri dari orang-orang yang memiliki kemampuan, baik di bidang hukum muamalah, hukum ekonomi dan perbankan, serta kemampuan lain yang relevan dengan tugas kesehariannya. Anggota DPS juga harus memiliki integritas, kompetensi dan reputasi keuangan. Anggota DPS terdiri dari pakar di bidang syariah muamalah yang juga mengetahui pengetahuan umum di bidang perbankan. Dalam melaksanakan tugasnya, DPS wajib mengikuti fatwa DSN mengenai kesesuaian produk dan jasa bank dengan ketentuan dan prinsip syariah. Tugas utamanya adalah mengawasi kegiatan usaha lembaga keuangan syariah agar sesuai dengan ketentuan dan prinsip syariah yang telah difatwakan oleh DSN. Sedangkan, Dewan Syariah Nasional (DSN) Majelis Ulama Indonesia (MUI) menerangkan bahwa DPS adalah badan yang ada di Lembaga Keuangan Syariah (LKS) yang bertugas mengawasi pelaksanaan keputusan DSN di lembaga keuangan syariah. Anggota DPS diusulkan oleh Rapat Umum Pemegang Saham (RUPS) dan penempatannya di bank syariah harus mendapatkan persetujuan DSN. Fungsi utamanya adalah sebagai penasehat Kesesuaian Fatwa DSN.... 
dan pemberi saran kepada direksi, pimpinan unit usaha syariah, dan pimpinan kantor cabang syariah mengenai hal-hal yang terkait dengan aspek syariah. DPS wajib mengacu pada fatwa-fatwa DSN dalam melaksanakan tugasnya. Sejak awal bank syariah harus menyertakan calon anggota DPSnya untuk dimintakan rekomendasi dari DSN dan selanjutnya dilakukan uji kelayakan dan kepatutan oleh Bank Indonesia. Sebagai pengawas syariah, fungsi DPS sangat strategis dan mulia, karena menyangkut kepentingan seluruh pengguna lembaga tersebut. Umat Islam akan selalu berpedoman pada keberadaan DPS karena dari sinilah kepercayaan pada bank syariah tersebut ditumbuhkan. Jumlah anggota DPS di bank syariah sedikitnya dua orang dan sebanyakbanyaknya setengah dari jumlah Direksi. Masa jabatannya paling lama sama dengan jabatan anggota Direksi atau Dewan komisaris. Anggotanya hanya boleh merangkap jabatan sebagai anggota DPS sebanyak-banyaknya pada dua lembaga perbankan dan dua lembaga keuangan syariah non bank. Satu anggota DPS diperbolehkan merangkap jabatan sebagai anggota DSN. Anggota DPS digolongkan sebagai pihak terafiliasi bank syariah.

Salah satu perbedaan yang mendasar antara struktur organisasi Lembaga Keuangan Syariah (LKS) dan lembaga keuangan konvensioanal adalah adanya keharusan Dewan Pengawas Syariah (DPS) pada lembaga keuangan syariah. Dewan pengawas syariah merupakan dewan pakar ekonomi dan ulama yang menguasai bidang fiqh mu'amalah (Islamic commercial jurisprudence) yang berdiri sendiri dan bertugas mengamati dan mengawasi operasional lembaga keuangan syariah dan semua produk-produknya agar sesuai dengan ketentuan-ketentuan syariah.

Perbedaan laian antara lembaga keuangan syariah dengan lembaga keuangan konvensional adalah adanya kewajiban pemenuhan kepatuhan pada prinsip syariah. Setiap pelaksanaan kegiatan usaha pada lembaga keuangan syariah wajib memenuhi kepatuhan pada prinsip syariah yang terimplementasi dalam produk, jasa dan operasionalnya. Kepatuhan pada prinsip syariah adalah suatu bentuk pelaksanaan akad dalam perbankan syariah yang berdasarkan prinsip-prinsip syariah. Sedangkan, prinsip syariah adalah perjanjian berdasarkan hukum Islam antara bank dan pihak lain untuk penyimpanan dana dan atau pembiayaan kegiatan usaha, atau kegiatan lainnya yang dinyatakan sesuai dengan syariah. ${ }^{11}$

Dewan Pengawas Syariah yang diberi tugas dan amanah untuk mengawasi setiap produk-produk yang dikeluarkan oleh Lembaga keuangan syariah dengan tetap menjaga kepatuhan syariahnya. Maka jika luput dari pengawasannya tetunya dapat merusak citra dan kredibilitas bank syariah di kalangan asyarakat sehingga dapat menurunkan kepercayaan masyarakat pada bank syariah. Bank syariah sebagai penghimpun dan penyalur dana publik wajib memiliki tigkat kepercayaaan yang tinggi dalam masyarakat dan dalam dunia usaha. Popularitas bukanlah satu hal yang mudah, namun harus dilakukan dengan penuh kedisiplinan dan bersungguh - sungguh. Apabila amanah telah diperoleh maka upaya untuk mempertahankan status juga bukan suatu hal yang mudah. Satu kesalahan kecil

${ }^{11}$ Ahkmad Faozan, Optimalsasi Peran Dewan Pengawas Syariah Pada Lembaga Kenangan Syariah, El Jizya, Vol 2 No 1 (2014) h, 1-18

Kesesuaian Fatwa DSN.... 
dapat merubah keyakinan masyarakat terhadap bank syariah. Oleh sabab itu sangat penting fungsi DPS pada bank syariah harus benar-benar dimaksimalkan, kriteria menjdi seorang DPS wajib diperketat serta dirumuskan perannya dan direalisasikan pada bank syariah tersebut.

Menurut UU No. 40 Tahun 2007 Pasal 109 disebutkan bahwa

1. Perusahaan yang menjalankan bisnis dengan prinsip syariah selain memiliki dewan komisaris juga memiliki dewan pengawas syariah.

2. Dewan pengawas syariah sebagaimana dimaksud pada ayat (1) terdiri atas orang-orang yang ahli syariah atau lebih yan ditunjuk oleh RUPS atas rekomendasi dari Majelis Ulama Indonesia

3. Dewan pengawas syariah sebagaimana dimaksud pada ayat 1 adalah petunjuk dan nasehat kepada direksi dan mengawasi kegiatan-kegiatan perusahaan untuk mematuhi prinsip-prinsip syariah.

Menurut undang-undang ini setiap badan hokum atau perusahaan yang beroperasi pada prinsip syariah wajib memiliki DPS. Oleh sebab itu UU No. 21 Tahun 2008 pada pasal 32 menyebutkan bahwa:

1. Dewan pengawas syariah hendaknya dibentuk oleh Bank syaiah dan Bank Umum Konvensional yang memiliki Uni Usaha Sariah (UUS)

2. Dewan pengawas syariah sebagaimana dimaksud pada ayat 1 ditetapkan oleh rapat umum pemegang saham atas rekomendasi Majelis Ulama Indonesia

3. Dewan pengawas syariah sebagaimana yang dimaksud pada ayat 1 betugas memberikan nasihat dan saran kepada direksi serta mengawasi kegiatan bank agar mematuhi prinsip-prinsip syariah

4. Ketentuan lebi lanjut mengenai berdirinya Dewan Pengawas Syariah sebagaimana dimaksud pada ayat 1 diatur oleh Bank Indonesia

Berdasarkan Undang-undang Perbankan Syariah pasal 32, maka perbankan syariah harus mendirikan DPS sebagaimana yang dimandatkan oleh Undang-Undang No. 21 Tahun 2008. Menurut penulis masih banyak Lembaga keuangan Syariah di Indonesia terutama Bank Syariah ataupun lembaga keuangan bank syariah sampai saat ini belum patuh terhadap fatwa DSN MUI atas produkproduk yang dikeluarkannya sehingga ke syariahan produknya masih dipertanyakan.

\section{Kesimpulan}

Berdasarkan hasil penelitian tentang kesesuaian fatwa DSN MUI No. 4 Tahun 2000 pada pembiayaan murabahah di bank syariah mandiri KCP Padang Panjang, maka penulis berkesimpulan bahwasannya pembiayaan murabahah salah satu bentuk pembiayaan yang paling banyak diminati dan diajukan nasabah di bank syariah mandiri KCP Padang Panjang dalam kegiatan konsumtif. Akad dan standar operasional prosedurnya telah berpedoman pada fatwa DSN MUI, Undang-undang perbankan syariah, Peraturan Bank Indonesia dan Otoritas Jasa Keuangan. Akan tetapi ada beberapa ketentuan pada prakteknya di bank syariah mandiri KCP Padang Panjang belum 
sesuai dengan fatwa DSN MUI No. 4 Tahun 2000 .

\section{Daftar Pustaka}

Adrian Sutedi, S H, Aspek Hukum Otoritas Jasa Keuangan (RAS, 2014)

Arief, Hidayatul, Iiz Izmuddin, and Hesi Eka Puteri, 'Pengaruh Financial Sustainability Terhadap Jangkauan BPR Syariah Di Propinsi Sumatera Barat', Ekonomika Syariab: Journal of Economic Studies, 3.2 (2019), 32-46

Ascarya, 'Akad Dan Produk Bank Syariah', Rajawali Pers, 2013

Fadhila, Novi, 'Analisis Pembiayaan Mudharabah Dan Murabahah Terhadap Laba Bank Syariah Mandiri', Riset Akuntansi Dan Bisnis, 2015 <https://doi.org/https://doi.org/10.30 596/jrab.v15i1.427>

Fathoni, Nur, 'Konsep Jual Beli Dalam Fatwa DSN-MUI', Economica: Jurnal Ekonomi Islam, 4.1 (2013), 51-82

Fatihudin, Didin, 'Metodologi Penelitian Untuk Ilmu Ekonomi, Manajemen Dan Akuntansi: Dari Teori Ke Praktek' (Zifatama Publishing, 2015)

Fauziyah, 'Penerapan Akad Murabahah Sesuai Fatwa DSN-MUI Studi Kasus Pada BRI Syariah KCP Lubuk Pakam' (UIN SUMATERA UTARA, 2019)

Hakim, L., and A. Anwar, 'Pembiayaan Murabahah Pada Perbankan Syariah Dalam Perspektif Hukum Di Indonesia', Al-Urban, $1.2 \quad$ (2017), 212-23 https://doi.org/10.22236/alurban

Handayani, Asri, Heru Aulia Azman, and Ismail Novel, 'Pengaruh Pengetahuan Dan Sikap Terhadap Perilaku Memilih Bank Syariah Dengan Faktor Religiusitas Sebagai Moderating Variable', EKONOMIKA SYARLAH: Journal of Economic Studies, 3.1 (2019), 1-19
IAIN Imam Bonjol Padang, Pedoman Penulisan Karya Ilmiah (Tugas Akhir, Skripsi, Tesis, Dan Disertasi (Indonesia, 2014)

Ilhami, Haniah, 'Pertanggungjawaban Dewan Pengurus Syariah Sebagai Otoritas Pengawas Kepatuhan Syariah Bagi Bank Syariah', Mimbar Hukum-Fakultas Hukum Universitas Gadjah Mada, 21.3 (2009), 476-93

Illahi, Ilham, 'Fenomena Manajemen Laba Pada Perbankan Syariah Di Indonesia Dan Tindakan Mitigasinya', EKONOMIKA SYARIAH: Journal of Economic Studies, 3.2 (2019), 1-13

Imama, Lely Shofa, 'Konsep Dan Implementasi Murabahah Pada Produk Pembiayaan Bank Syariah', IQTISHADLA: Jurnal Ekonomi Dan Perbankan Syariah, 1.2 (2015), 221-47

Irawan, Feri, and Hesi Eka Putri, 'Interaksi Aspek Permodalan, Resiko Pembiayaan, Dan Indikator Makroekonomi Dalam Mempengaruhi Profitabilitas BPRS Di Indonesia Periode 2014-2018', Jurnal Benefita, 5.3 (2020), 401-12

Irfayunita, Febby, Miswardi Miswardi, and Hesi Eka Puteri, 'Pengaruh Nisbah Bagi Hasil Terhadap Preferensi Masyarakat Memilih Produk-Produk Pendanaan Pada Perbankan Syariah Dengan Faktor Financial Literacy Sebagai Variabel Intervening', Jurnal Benefita, 1.1 (2019), 14 $<$ https://doi.org/10.22216/jbe.v1i1.363 6>

Istiqlal, Cahyo Halim, 'Penilaian Kinerja Perbankan Syariah Dengan Metode Balanced Scorecard', Jurnal Fakultas Hukum UII, 3.2 (2009), 167-80

Lathif, Ah Azharuddin, 'Konsep Dan Aplikasi Akad Murabahah Pada Perbankan Syariah Di Indonesia', AHKAM: Jurnal Ilmu Syariah, 12.2 (2013)

Nelli, Fitra, 'Problematika Kiprah Dewan Pengawas Syariah Dps Di Perbankan Kesesuaian Fatwa DSN.... 
Syari'ah', Al-Masharif: Jurnal Ilmu Ekonomi

Dan Keislaman, 3.1 (2015), 85-98

Nursalam, 2016, metode penelitian, and A.G

Fallis, 'Konsep Keadilan Bagi Nasabah

Dalam Akad Murabahah Bil Wakalah di

Bank Syariah', Journal of Chemical Information and Modeling, 2013

Prabowo, Bagya Agung, and Jasri Bin Jamal, 'Peranan Dewan Pengawas Syariah Terhadap Praktik Kepatuhan Syariah Dalam Perbankan Syariah Di Indonesia', Jurnal Hukum IUS QUIA IUSTUM, 2017 $<$ https://doi.org/10.20885/iustum.vol2 4.iss1.art6>

Sugiyono, Metode Peneiltian Kuantitatif, Kualitatif Dan R\&D, Alfabeta Bandung, 2018

Sujamto, Beberapa Pengertian Di Bidang Pengawasan (Indonesia: Ghalia Indonesia, 1986)

SYUKRI ISKA, Sistem Perbankan Syariah Di Indonesia (Indonesia: Fajar Media Press, 2016)

USMAN, RACHMADI, Aspek Hukum Perbankan Syariab Di Indonesia (Indonesia: SINAR GRAFIKA, 2014)

Victor M. Situmorang, Aspek Hukum Pengawasan Melekat (Indonesia: Rineka Cipta, 1994)

Yusmad, Muammar Arafat, Aspek Hukum Perbankan Syariah Dari Teori Ke Praktik (Deepublish, 2018)

Zainul Arifin, M B A, Dasar-Dasar Manajemen Bank Syariah (Pustaka Alvabet, 2012) 